\author{
Agnieszka SADECKA ID \\ Jagiellonian University in Kraków \\ agnieszka.sadecka@uj.edu.pl
}

\title{
EXPORTING SOCIALISM OR SEARCHING FOR THE “THIRD WAY”?
}

\section{POLISH-INDIAN RELATIONS IN THE LENS OF POLISH SOCIALIST-ERA REPORTERS (1950s-1970s)}

ABSTRACT The article explores the perception of India in socialist-era Polish travel reportage, focusing in particular on the political debates inscribed in the Cold War divisions. Four books of reportage from India, by Jerzy Ros, Wiesław Górnicki, Janusz Gołębiowski, and Jerzy Putrament, serve as primary material for this research. The reporters, visiting India on official assignments, discuss the relations between the so-called Second and Third World and India's take on socialism. While the analyzed texts do not present a uniform vision, the reporters' narratives reveal an interesting relation of ambivalence: Indians are seen at times as socialist brothers, but at other times a rather patronizing attitude prevails.

Keywords: Poland, India, Cold War, Socialism, Post-colonialism 
The period of thaw after the death of Stalin led to a certain relaxation in the policy of closed borders in the Eastern Bloc. Ryszard Kapuściński, Wojciech Giełżyński, Wiesław Górnicki and many other top reporters of the time were finally allowed to travel abroad and bring news from the wider world to an avid Polish audience, tired of Stalinist isolation. What they brought back from their voyages were stories of revolutions, uprisings, new states forming, and old regimes falling. These were not merely exciting tales from exotic countries - although to some, they may have appeared as such - but they served as important tools of shaping a new socialist worldview. In the times of Cold War rivalry, it was important to present countries of the so-called Third World, formally non-aligned with the socialist block, as de facto allies in the struggle against the West and capitalism. The communist authorities in Moscow, as well as their emanations in Warsaw, Prague or Budapest, were eager to welcome the former colonies in the socialist family. Not only it could add importance to the Soviet Bloc on the global arena, but it could also help convince their own citizens of the benefits of the communist system. After all, if newly independent states freely adopted socialist principles and believed in communism, why would the inhabitants of Eastern Europe want to reject the system? This article focuses on various political narratives found in works of Polish reportage of the socialist era written by prominent journalists and commentators. The main research question is how was socialism positioned in these works of nonfiction in two national contexts: of reporters' native Poland, and of the visited country, namely India. For that purpose, four booklength reportages were chosen as study material. A close reading and interpretation of the key frames of portrayal of socialism in India is the method adopted.

As Artur Domosławski recounts in the biography of the most famous Polish reporter of that era, Ryszard Kapuściński, the Press Office of the Polish communist party decided to send journalists to countries of the global South in the name of the socialist camp's friendship with the Third World. ${ }^{1}$ India was a key destination for Polish reporters: not only thanks to the leftist views of its political leaders, but also because it was considered an important economic partner in trade and a large market for exported goods. Furthermore, India would arise public interest in Poland as an old, rich culture and the former jewel in the crown of the British Empire which chose independence. The analysis of four books of reportage from India, by Jerzy Ros, Wiesław Górnicki, Janusz Golębiowski, and Jerzy Putrament, is particularly relevant in this respect. How was India perceived by the Polish reporters? What were their characterizations of Indian socialism? Were they trying to export socialist ideas and engage with their fellow travelers, or - on the contrary - were they influenced by Indian political solutions? To answer these questions, three dimensions of Polish-Indian contacts from the socialist era, as portrayed in the works of reportage, will be analyzed: the contacts resulting from the economic exchange, the reporters' encounters with Indian communists, and, finally the 'meeting of ideas' from the Polish and Indian socialisms. ${ }^{2}$

\footnotetext{
A. Domosławski, Kapuściński non-fiction, Warszawa 2010, p. 134.
}

2 Other narratives and representations of India in the texts of the aforementioned reporters are analyzed 


\section{NEW CONNECTIONS: SECOND WORLD AND THIRD WORLD}

Today, the Second World is remembered as a space full of confines, borders, and divisions, characterized by the lack of free movement and isolationism. However, its selfstyled image was one of a champion of internationalism and worldwide brotherhood of workers. Actually, these two contradictory images can be considered as valid, but in two different ways. While individuals were limited in their freedom to travel within and outside of their states, the communist governments appealed for international proletarian solidarity in bringing down capitalism. To this end, exchange between socialist countries was encouraged (albeit in a highly controlled manner), and, gradually, the Second World would reach out to the countries of the so-called Third World. According to Babiracki and Jersild, by the time the Second World came into being, 'internationalism' evolved from a revolutionary program into something of a condition, a state, and a situation, which included diverse forms of international entanglements. ${ }^{3}$ The contacts between the Soviet Union and India were part of these entanglements, and have undergone various phases.

In the first years of decolonization of the Indian Subcontinent, the Soviet Union and the newly independent Indian state did not seem to be headed towards an intensive cooperation. Stalin was distrustful of Nehru's foreign policy, which he accused of being a play between England and America. ${ }^{4} \mathrm{He}$ also criticized the bourgeois character of India's political elites and perceived them (and other post-colonial governments) to be tools of Western imperialism. Nevertheless, after Stalin's death in 1953, the attitudes in Moscow changed. Stalin's successors were favorable to India and ready to intensify mutual exchange between India and the countries of the Soviet Bloc. Indeed, Soviet-Indian ties strengthened over time, undergoing various phases of distancing and rapprochement. According to Vojtech Mastny, there were three periods, symbolically represented by three pairs of leaders: Jawaharlal Nehru - Nikita Khrushchev, Indira Gandhi - Leonid Brezhnev, and Rajiv Gandhi - Mikhail Gorbachov. ${ }^{5}$

Jawaharlal Nehru's newly independent India was a champion of the doctrine of nonviolence and led the non-alignment movement formed at the 1955 Bandung Conference. Nehru believed India to be uniquely capable of guiding the world away from the perilous confrontation between the superpowers. ${ }^{6}$ One of these superpowers, however,

more in detail in the author's doctoral dissertation, "Exotic Others or Fellow Travellers? Representations of India in Polish Travel Writing during Communist Era”, Eberhard Karls Universität Tübingen, Universitätsbibliothek Tübingen, TOBIAS-lib: Tübingen 2018.

3 P. Babiracki, A. Jersild, "Editors' Introduction”, in eidem (eds.), Socialist Internationalism in the Cold War, Basingstoke 2016, p. 5.

4 A. Hilger, "The Soviet Union and India: The Years of Late Stalinism", Parallel History Project on Cooperative Security, Swiss Federal Institute of Technology, IX 2008, at http://www.php.isn.ethz.ch/ lory1.ethz.ch/collections/coll_india/intro_stalinee91.html?navinfo=56154, 4 September 2021.

5 V. Mastny, “The Soviet Union's Partnership with India", Journal of Cold War Studies, vol. 12, no. 3 (2010), pp. 50-90.

6 Ibid., pp. 52-53. 
was closer to Nehru's heart - although he considered the Soviet Union as sinful as the United States, he found it to be more capable of redemption because it was un-tainted by the evils of racism and colonialism. ${ }^{7}$ Likewise, the Soviet Union led by Khrushchev was over time becoming more eager to establish closer links with India, especially as its relationship with China worsened. Soon, the USSR became the main provider of equipment - arms, vehicles, and planes - for Indian military, and an important economic partner. This period of friendship suffered a crisis when, to the dismay of Indian politicians, the Soviets failed to support India in its war against China in 1962, which India eventually lost.

When Indira Gandhi took power after her father's death, she proved to be much less idealistic in her approach to the Soviet Union. She continued to cooperate with the USSR, but also accepted economic aid from the United States (which far exceeded the widely propagated Soviet aid to India). Similarly pragmatic in his attitudes, Brezhnev insisted on maintaining good relations with India, and in 1971, the two countries signed a treaty of peace, friendship, and cooperation. It reflected Moscow's hope that India will be the socialist countries' bridgehead in Asia. ${ }^{8}$ While Indira Gandhi welcomed Soviet support during the war with Pakistan (which lead to the split into Pakistan and India-backed Bangladesh), her rule did not lead to much advances of socialism in ideological and economic terms. Indira's successor, her second son, Rajiv, took reigns in the midst of turmoil following the 1984 assassination of his mother. At that time, the Soviet Union was weakened by the war it was leading in Afghanistan and by economic problems. Gorbachev's ideas of disarmament were matched by Rajiv Gandhi's peaceful stance - the two countries were resolved to continue their cooperation, especially in the fields of science and technology. However, global changes were on the horizon: soon, the Soviet Union collapsed and India turned its gaze towards the West.

On the level of ideas, however, India remained nostalgic about socialism, and the numerous Indian communist movements remain as loyal to Marx and Lenin (some even to Stalin) as ever. ' Why? The Soviet Union's message of support to the countries of the Third World was heard loud and clear in the countries which strived for recognition on the global arena after years of colonialism. The values heralded (if hardly applied) by the USSR: equality, fairness, better distribution of goods, wide access to social services, etc., resonated in a country like India, which battled poverty, social divisions, and the aftermath of colonial exploitation. Even though the Soviet Union's commitment to India was fleeting and dependent on immediate political goals, it left a strong imprint on the history of India's relations with Eastern Europe. The Soviet Union created an alternative model to westernization, with its own ideas, values, concepts of development and progress. According to Alfred Rieber, the promise of socialist interna-

\section{Ibid., p. 53.}

8 Ibid., p. 71.

9 See: K.N. Ramachandran, "History of the Communist Movement in India", CPI(ML) Red Star 23 IX 2019, at http://www.cpiml.in/cms/documents-2/party-school-papers/item/2284-history-ofthe-communist-movement-in-india-kn-ramachandran, 4 September 2021. 
tionalism constituted a vision of mutually enriching cultural ties, 'visible and invisible,' which would eliminate the divisive and destructive conflicts among classes and nations and bind people together in a socialist commonwealth.$^{10}$ Indeed, the Soviet Union attempted at strengthening its influence not only by political and economic means, but also by inviting students and researchers to study at the Soviet universities and by providing them with scholarships. According to Griffiths and Cardona, this was yet another form of soft power: educational aid could contribute to such goals by producing graduates fluent in Russian, with knowledge of and a sympathetic disposition toward the Soviet political economy, its political structures, systems, and economic plans, and toward the Soviet approach to questions of national economic development. ${ }^{11}$ It is thus understandable that despite internal problems in the Soviet Bloc, its global image, particularly in the newly decolonized countries, was positive.

It was also an effect of a carefully orchestrated propaganda. For instance, in one of the Polish reporters' books, an interesting depiction of the two Cold War rivals, the Yankees and the Ruso can be found. Wojciech Giełżnnski in his Medytacje o Świecie Trzecim (1972), says that while the Yankees were a vague, unreal concept to the inhabitants of the Third World, the Ruso - or the Soviet - myth was powerful: The Ruso could even defeat the Yankee if he only wanted, he is the stronger one - and he could divide his riches among the poor. "Ruso" is thus like Robin Hood, but also like the Messiah, because he was the one who invented SOCIALISM ${ }^{12}$, the efficient cure for all; he is also partly a Martian [an alien], because he is a rare type, hundredfold more difficult to spot with one's own eyes than the "Yankee" $[. ..] .^{13}$

Apart from these semi-mythical representations of the Soviets in the countries of the Third World, Giełżyński points out that there were strong reasons for liking the USSR - the main one was the economic assistance. The reporter underlines that unlike the Americans, the Soviets offered their help with no strings attached, they were not leading a neocolonial economic policy as the West does. ${ }^{14}$ Despite such assurances, the story of Soviet relations with India does not prove that Soviet friendship was a purely selfless affair - quite the opposite: when Moscow needed Delhi's support in an international cause, the friendship declarations grew stronger, while real help, like in the IndoChinese war, was not always provided. When the Soviet Union sent experts to India in

10 A. Rieber, "Afterword: Promises and Paradoxes of Socialist Internationalism (Personal and Historical Reflections", in P. Babiracki, A. Jersilsd (eds.), Socialist Internationalism in the Cold War, Basingstoke 2016, p. 329.

11 T.G. Griffiths, E.C. Cardona, "Education for Social Transformation: Soviet University Education Aid in the Cold War Capitalist World-System”, European Education, vol. 47 (2015), p. 231.

12 Original capitalization.

13 W. Giełżyński, Medytacje o Świecie Trzecim, Warszawa 1972. My own translation from the original: Wszak 'Ruso' mógtby pokonać nawet 'Janki', gdyby tylko zechciat, jest od niego silniejszy - i mógtby podzielić między biednych jego bogactwa. 'Ruso' jest więc Robin Hoodem, ale jest i Mesjaszem, bo on wtaśnie wymyślit SOCJALIZM, skuteczny lek na wszystko, jest także po trosze Marsjaninem, jako okaz niezwykle rzadki, stokroć trudniejszy do obejrzenia na wtasne oczy niż 'Janki' [...], p. 203.

14

Ibid., p. 205. 
order to advise the newly formed state, it was not only a gesture of friendship, it was also a calculated strategy to compete with America over influence in South Asia. Certainly, Soviet Bloc experts would encourage the idea of central planning and praised India's Second Five-Year Plan as they deemed it similar to Soviet plans. However, even in this praise, a feeling of superiority could be discerned. David Engerman observes that the relation between India and the Soviet Union was not an equal one. The Soviets would cast themselves in the role of elder brother to the nations of the Third World in a similarly paternalistic manner as they did for Soviet republics or satellite states. ${ }^{15}$ Analyzing Polish-Indian relations in the socialist era, one needs to keep in mind this complicated web of power relationships: Poland, a satellite state of the Soviet Union, is looked down upon from Moscow. At the same time, in the Polish-Indian interaction, Polish travelers reproduce, to some extent, the same feeling of superiority towards India as their Soviet counterparts.

\section{COMMUNIST POLAND AND SOCIALIST-ORIENTED INDIA}

Nevertheless, since the official beginning of diplomatic relations between Poland and independent India in 1954, the two countries entered a fairly intensive relationship. In 1955, Jawaharlal Nehru came on a state visit to the Soviet Union and Poland, and two years later, Polish Prime Minister, Józef Cyrankiewicz, visited India. In 1957, the Indian Embassy was established in Warsaw, and in the same year, an Agreement on Cultural Cooperation and subsequent Cultural Exchange Programs was signed. The Polish socialist government organized courses and scholarships for students from developing countries, including India. Several large investments in industry were undertaken with the Soviet aid, for instance the Bhilai steel mill, designed with the help of Polish engineers, as well as coal mines where miners from Poland were employed.

To make the Polish society aware of this new Indian connection and of the People's Republic of Poland global outreach, the media - all of them state-owned at the time - began to explore these new, exotic topics. Several reporters were sent to India to describe the reality of the decolonized country on the path to socialism (as Polish communist authorities believed). In their texts, the reporters do not mention the story behind their journey to India: what recommendations they received from their superiors, what they heard on their passport interviews and what their entanglements with secret services were (as it is now widely known from Ryszard Kapuściński’s biography and archival files of the secret services, it was common practice to make journalists travelling abroad sign loyalty contracts and commit to report to the authorities immediately after the return). The analysis of reporters' accounts from India demonstrates that their itineraries were to some degree set according to a similar pattern: they traveled to large cities and key touristic sites, described poor neighborhoods and luxurious palaces, and

15 D.C. Engerman, "Learning from the East: Soviet Experts and India in the Era of Competitive Coexistence", Comparative Studies of South Asia, Africa and Middle East, vol. 33, no. 2 (2013), p. 227. 
made contact with local communist activists. Moreover, they would visit the "Polish spots" on India's map: steel mills and coal mines where Polish experts would be found. Such descriptions appear in Janusz Gołębiowski's Nadane z Delhi [Posted from Delhi] (1966) and in Jerzy Putrament's Na drogach Indii [On the roads of India] (1967). The following section focuses on the representations of Polish experts and workers in India as given in the two works of reportage.

\section{POLISH-INDIAN ECONOMIC EXCHANGE AS PORTRAYED IN REPORTAGE}

Both reporters were on an official appointment: Janusz Golębiowski as Polish Press Agency's correspondent in New Delhi, and Jerzy Putrament - writer, communist activist, a mighty figure in the socialist cultural life (for years, president of the Polish Writers' Union) -as member of an official delegation to India. Janusz Gołębiowski often mentions the Polish-Indian economic cooperation and, while in India, is on the lookout for products made in Poland. Apart from mines, steel plants, electric plants, Poland also began to export tractors and motorcycles to India. Several agreements were signed in 1960s and 1970s: on economic cooperation $(1960,1962,1965)$, on sail (1960) and air transport (1977) and on economic, industrial, and technical cooperation (1977). Nevertheless, the reporter notices that the lack of knowledge of local conditions caused many vehicles to fail - tires were not strong enough for Indian roads, engines would overheat in the hot climate. ${ }^{16}$ The fact that he notices these shortcomings is telling; the reporter maintains a certain distance and does not give in to a blind admiration of all trade initiatives undertaken by the Polish government. The reporter is also interested in the intensified cultural exchange between Poland and India. He mentions the Poland and Polish Perspectives magazines available at the press club in Delhi and occasional exhibitions of graphic art, books or artistic photography, but he realizes that these events have limited outreach and Indian knowledge of Poland remains meagre. ${ }^{17}$ That is why he believes that a good reputation worldwide is contingent on, above all, economic progress and trade relations.

Putrament focuses on these aspects when he visits the coal mines in Gidi and Sudamdih in the state of Bihar. There, he meets a group of Polish miners sent to instruct their Indian colleagues on mining techniques. His visit coincides with the celebration of Barbórka, a festivity in the honor of Saint Barbara, the patron saint of miners. Most Polish miners originally came from the region of Silesia, in Western Poland, and Putrament experienced some of the Silesian folklore and Polish-style celebrations. It included singing, dancing, and vodka, which the author calls ironically the chief deity of the Slavs, ${ }^{18}$ taking an opportunity to refer in a derisory manner to the ever-present deities

16 J. Gołębiowski, Nadane z Delhi, Warszawa 1966, p. 160.

17 Ibid., pp. 156-157.

18 J. Putrament, Na drogach Indii, Warszawa 1967. My own translation from the original: naczelne bóstwo Stowian, p. 60. 
of the Hindu pantheon. The reporter recalls that the Indian guests at the party were slightly confused by what was happening, just like us looking at the strangest Hindu customs in Benares. ${ }^{19}$ Benares (today Varanasi) is considered one of the holy places for Hindus, therefore this comment can be read as another veiled criticism of Indian religiosity. A common theme in Polish socialist reportage from India, the promotion of atheism referred to as rationality - and an ironic attitude to religion in general serve a double goal: not only do they present Indian religious traditions as obsolete, obscurantist and backward, effectively an obstacle to progress, but also instill such an understanding of religion in their Polish readers, still by and large attached to their Catholic faith.

Another of Putrament's observations while in Sudamdih seems to be again intended for his Polish readers, this time expressed in a very open, if not preachy, tone. Putrament is proud and satisfied to see Polish miners in India, considering it to be the proof of Poland's technologic progress and modernity. He compares this with his recollections of Polish miners in France before the war. There, he says, they were just cheap labor, employed for jobs that locals found too hard. Here - they are specialists, best paid, most qualified. It is not difficult to [see] the contrast: in the past we were exporting labor, numbers, resources, today we export reason, quality, finished products, complete industrial sets. You can shout, you can fuss, you can bad-mouth, you can complain, but your clatter is not going to undo some changes. It is a different country, Poland of the 60s and Poland of the 30 s, and even ifyou stood on your head, it is closer to the world's top than thirty years ago. ${ }^{20}$

Putrament praises the Polish specialists in India, but he also uses this to provide arguments against the critics of the socialist system and to legitimize it. The use of the personal pronoun, you (you can shout, you can fuss, you can bad-mouth) reinforces the feeling that Putrament has specific groups of critics in mind, whom he addresses in a straightforward manner. The clash of two images, of Poland in the 1930s and Poland in the 1960s, is yet another discursive trick to show a sharp contrast between a poor country exporting unskilled laborers and a country of socialist progress, ever closer to the world's top, exporting reason, quality, finished products, complete industrial sets. This image is certainly an idealized one, as Putrament seems to ignore the fact that many Poles emigrated to the West throughout the years of communist rule, seeking freedom and better life, even at the cost of becoming simple laborers. ${ }^{21}$

19 Ibid. My own translation from the original: Hindusi siedzieli z boku, patrzac na widowisko z nie mniejsza zachtannością i zadziwieniem, niż my oglądajacy najdziwaczniejsze zwyczaje hinduskie w Benaresie, p. 60. Ibid. My own translation from the original: Tu - to sa specjaliści, najlepiejptatni, najbardziej wykwalifikowani. Nietrudno o przeciwstawienie: ongi wywozilismy sitę, ilość, surowce, dziś wywozimy rozum, jakość, gotowa produkcje, gotowe cate obiekty przemystowe. Krzyczcie i wydziwiajcie, plotkujcie, narzekajcie, pewnych przemian wasz najgorszy jazgot nie odmieni. To inny kraj, Polska lat 60-tych niz Polska lat 30-tych, i choćbyście na gtowie stanęli, bliżej jej teraz do światowej czotówki niż trzydzieści lat temu, pp. 58-59.

21 The emigration of Poles in the communist era is even called by some the second great emigration (after the Great Emigration of the $19^{\text {th }}$ century), and historians evaluate that up to one million people left the country in the years 1949-1989 despite difficulties in obtaining passports and other documents. See: D. Stola, Kraj bez wyjścia? Migracje z Polski 1949-1989, Warszawa 2010, also J. Krzyk, "Druga wielka emigracja”, Ale Historia, 13 July 2015, at http://wyborcza.pl/alehistoria/1,121681,18340374,drugawielka-emigracja.html, 4 June 2021. 
Further, Putrament visits the electric plant in Barauni, constructed with the assistance of Polish engineers. He relates his conversations with them in which they complain about various difficulties (heat, monsoons, mosquitoes, and scorpions ${ }^{22}$ ) and among others, about their problems with the Indian workers, who they view as lazy and disobedient. They just don't do anything. They wander back and forth, and one cannot catch them and put them to work. And even if you do, you can't watch over them [...]. No, sir, the English knew what they were doing when they kept them at tight leash! Otherwise, they don't do anything [...]. ${ }^{23}$ Putrament finds this opinion extreme, and, realizing how inappropriate it sounds, underlines that it was uttered only by one person; nevertheless, he suspects that more Poles share this view ${ }^{24}$. On the surface, he is disturbed by the admiration for colonial rule in India, but his own feeling of superiority over Indians and sympathy towards fellow Poles is evident. Despite his declarations about respecting cultural differences and learning about Indian customs, he remains Polish-centric in his worldview, following in the footsteps of many travelers of the previous era who used meetings with natives to boost themselves as more civilized, knowledgeable, rational, and cultured..$^{25}$ Despite the problems encountered by Polish experts in India, Putrament is of the opinion that it is good for Poles to work in respected jobs abroad as they bring their income earned there back to the country and also learn to appreciate the Polish standards better. ${ }^{26}$

It is thus easy to notice that maintaining trade relations, helping in India's industrial development, and exporting specialized workers to the Third World often have a propagandist angle for Poland. To illustrate it, it is enough to mention that at some point of his narrative, Putrament - in his capacity of Polish Writers' Union vice-president openly recommends to fellow writers to cover this aspect of Polish presence abroad instead of inventing fictional plots. He finds that Polish literature, closely watching the literary trends in the West, fails to do justice to momentous changes in the Polish national consciousness, which is in the process of becoming more global. ${ }^{27}$

\section{SOCIALIST BROTHERHOOD: MEETINGS WITH INDIAN SOCIALIST ACTIVISTS}

Another way of presenting this global dimension of socialist consciousness in travel reportages from India was through the depiction of communist brotherhood which transcends boundaries of states and cultures. It was a common feature of many socialist

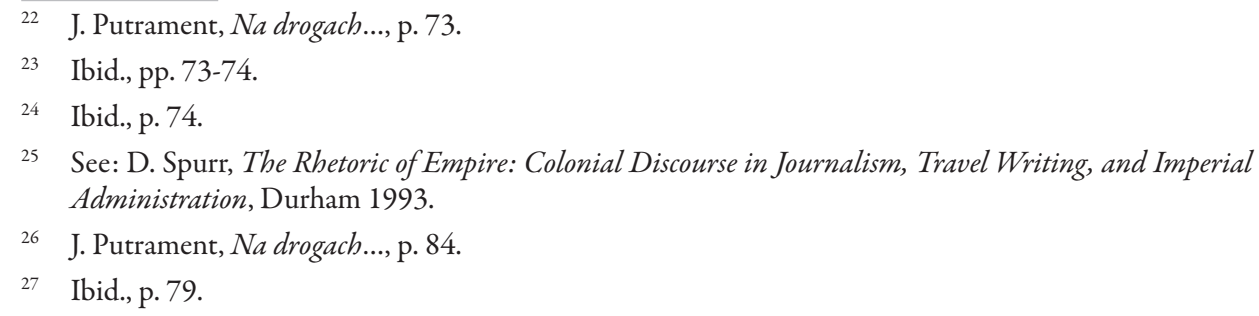


travel accounts to show the reporters directly engage with Indian communists, workers, and activists. They describe working-class districts of big cities, everyday concerns of people, and they talk to party members or attend party meetings. Two texts can be mentioned here: Jerzy Ros' Indyjskie wędrówki [Indian Wanderings] (1957) and Wojciech Giełżyński’s Kraj świętych krów i biednych ludzi [The Country of Holy Cows and Poor People] (1977). The prime location that the reporters visit in order to describe the Indian communist movement is usually Kolkata, ${ }^{28}$ a city famous for its leftist tendencies. Ros describes it in the following way.

Calcutta is a large center of workers' movement, industry and transport here gave birth to a strong working class, organized in trade unions and in the Communist Party of India. But at the same time, Calcutta is a center for reactionary, orthodox groups, preying on chauvinism and religious fanaticism. ${ }^{29}$

The reporter notices slogans that call for cooperation with China, and a struggle for peace and bread, but also nationalist and backward ones, against murdering of cows. ${ }^{30}$ This clash of ideas is emblematic of how he perceives India: as a country where two powerful forces are at work - progressive (communist), and conservative (nationalist, reactionary). As it can be expected, the reporter takes a clear stand, supporting the communists. His focus is not merely on the political movement; Ros goes beyond slogans and visits poor neighborhoods, interviews a rickshaw-puller, a president of a trade union of textile workers, as well as a proletarian Bengali poet, with whom he toasts to Polish-Indian friendship, to Stalingrad, and to heroic Warsaw. ${ }^{31}$ His guide, a journalist from a local leftist newspaper, introduces him as a guest from a country, where the land belongs to peasants, factories to workers, and schools are open to everyone free of charge. ${ }^{32}$ Ros himself paints an optimistic picture of his country of origin - when asked about Poland, he talks about, in his words, the most usual things: new construction projects and free education, healthcare and holidays, maternity leaves and kindergartens. ${ }^{33}$ But he realizes that for his Indian interlocutor, all of it is "social exotic," very removed from his everyday experience, and thus hardly believable. ${ }^{34}$

28 In the article, current names of Indian cities are used (e.g. Kolkata, Mumbai), however quotations from the original reportages retain older names (Calcutta, Bombay).

29 J. Ros, Indyjskie wędrówki, Warszawa 1957. My own translation from the original: Kalkuta jest wielkim centrum ruchu robotniczego, przemyst i transport zrodzity tu silna klasę robotnicza, zorganizowana w zwiazkach zawodowych i w Komunistycznej Partii Indii. Ale jednocześnie Kalkuta stanowi ośrodek reakcyjnych, ortodoksyjnych ugrupowań, żerujacych na szowinizmie i fanatyzmie religijnym, p. 176.

Ibid., p. 176.

31 Ibid., p. 250.

32 Ibid. My own translation from the original: kraju, gdzie ziemia należy do chtopów, fabryki do robotników, a szkoty otwarte sa dla wszystkich bezptatnie, p. 137.

33 Ibid. My own translation from the original: Mówitem o rzeczach najzwyklejszych: o nowym budownictwie i bezplatnej nauce, o lekarskiej opiece i wczasach, o urlopach macierzyniskich i przedszkolach. W pewnej chwili jednak uprzytomnitem sobie, że to, co mówię, jest w klimacie Indii socjalną egzotyką. Toteż nic dziwnego, że na twarzy mojego gospodarza maluje się zdumienie, że kiwa gtowa grzecznie, z podziwem, ale $i z$ widocznym powatpiewaniem, p. 141.

Ibid., p. 141. 
Once again, this conversation recalled by the reporter appears as instrumental in presenting Poland as a sort of socialist paradise, were citizens live happy, trouble-free lives and the state provides them will all the necessary services. But who is actually intended to see Poland in this manner: the Indians that the reporter encounters on his way, or his Polish readers? While sympathizing with the fate of the lowest classes of the Indian society, Ros remains intent on sending a message to his fellow citizens, showing how privileged they are in comparison. At the same time, his description of Poland can be read as a socialist promise, mentioned earlier in this article - a utopian vision of the future for the countries which will follow in the footsteps of the Soviet Union.

Giełżyński, too, visits the red Kolkata, where all troubles and failures of India are reflected. ${ }^{35}$ The reporter notes that the poverty and social divisions in the city are causes of ferment that might lead to revolutionary changes. He mentions the important role of the university in Kolkata, which he believes to be the best in all of India, but also the most radical politically: They say that it is the cradle of the socialist revolution, that it maintains close links to the worker activists. ${ }^{36}$ Of course, says Giełżyński, there are also many fanatics and reactionaries in the city, but workers are not as divided by caste there as in other parts of India: All this does not mean that the castes are only a cultural anachronism in Calcutta and that everyone is a fully aware fighter for new, socialist, and fair social relations. This is still very far away. But if one worker out offifty carries an ID card with a hammer and sickle, and one in ten understands exactly what do 'exploitation' and 'class struggle' mean - that, in Indian conditions, is a lot. It means that 'Red Calcutta' is the most progressive city in all India. ${ }^{37}$

Giełżyński thus considers Kolkata to be an experiment, a hopeful example for the rest of India. The workers across the country should be, according to the reporter, made familiar with the concept of workers' struggle and become members of the communist party (carry ID cards with the hammer and sickle).

During his journey throughout India, Jerzy Ros found that indeed, leftist ideas found some resonance among employees of state-owned industries (or at least the reporter wants to believe so). He describes his visit to the Golden Rock Railway Workshop in Tamil Nadu. He is interested not only in the technological advances, but first and foremost, in the views of the workers. He invites some of them to a local tea shop the workers welcome him warmly and make toasts to Warsaw. Here, they are inquisitive listeners, wanting to find out as much as possible about the country and the system that is

35 W. Giełżyński, Kraj świętych krów i biednych ludzi, Warszawa 1977, p. 82.

36 Ibid. My own translation from the original: Mówia o nim, że jest kolebka socjalistycznej rewolucji, że utrzymuje ściśte więzy z dziataczami robotniczymi, p. 83.

37 Ibid. My own translation from the original: Wszystko to nie znaczy, iz w Kalkucie już kasty sa tylko obyczajowym przeżytkiem $i \dot{z} e$ wszyscy sa już świadomymi bojownikami o nowe, sprawiedliwe, socjalistyczne stosunki spoteczne. Do tego wciąz bardzo daleko. Ale jeśli jeden robotnik na pięćdziesięciu nosi legitymacje z sierpem i mtotem, a jedne na dziesięciu doktadnie rozumie, co znaczy 'wyzysk' i 'walka klas' - to, windyjskich warunkach, bardzo wiele. To już oznacza, że 'Czerwona Kalkuta' jest najbardziej postępowym miastem w catych Indiach, p. 85. 
for them the symbol of equality between free individuals. ${ }^{38} \mathrm{His}$ new friends even accompany Ros to the train station, where he embarks on his journey back to Mumbai and then Poland. Ros is moved by their warmth and the emotional goodbyes. The farewell scene conveniently figures at the very end of the reporter's account and symbolizes the brotherhood of socialist India and socialist Poland through the unity of the working class.

Throughout his reportage, Ros indeed tries to establish a link between the Indians that he interviews and his readers, uniting them around the same cause, similar political ideas, and binding them with the same heart-felt desire for their countries' development. It is also the aim of other reporters, although they are less certain whether India really can be defined a socialist country and whether there really is a parallel between Polish and Indian workers. Despite his frequent calls for withholding judgment on other cultures or understanding different points of view, Giełżyński still draws a line between the European us and the Indian them. After finding out that at some construction sites of factories sponsored through Soviet credits, children are employed, Giełżyński concludes: [s]till, for us, people from Europe, especially from socialist countries, from Poland, it is difficult to accept many customs that one encounters there. It is particularly hard to turn a blind eye to the social relations, so contradictory to our ideals. ${ }^{39}$ Thus, for the reporter, even though India can boast about its industrialization and technological development, these do not go hand-in-hand with cultural modernity. Many of the Polish accounts from India actually revolve around the binary division between tradition and progress, illustrating it as a contrast between modern industrialization and traditional culture. After his visit in one of the industrial sites, Ros notices people watching a rooster fight. $\mathrm{He}$ treats this image as a metaphor of India: Steel and roosters - this is also India. For many years only the colorful, rooster-like exotics of this enormous country would be seen. Now, some would like to see here only iron. But the life and the truth of this country means that roosters fight at the threshold to large factories, in which steel is melted..$^{40}$

Through this metaphor, Ros suggests to the readers that neither an Orientalist view of India is a correct one, nor an exaggerated belief in modern technology. What defines India, he seems to say, is the contrast between the two, the exotic and the industrial.

There are many instances in the reporters' narratives in which they mention a meeting with a local leftist journalist or a conversation with a communist party member. It is not clear to what extent such meetings were set up: the reporters were certainly encouraged to write about socialism in India, but it is difficult to judge how free they were in

38 J. Ros, Indyjskie... My own translation from the original: Tu oni sq dociekliwymi stuchaczami, chcacymi dowiedzieć się jak najwięcej o kraju i ustroju, który jest dla nich symbolem sprawiedliwości panującej między wolnymi ludźmi, p. 344.

39 W. Giełżyński, Kraj... My own translation from the original: A jednak nam, ludziom z Europy, zwtaszcza z krajów socjalistycznych, z Polski, trudno przystać na wiele zwyczajów, które się tam spotyka. Trudno przede wszystkim przymknać oczy na stosunki spoteczne, tak bardzo sprzeczne z naszymi ideatami, p. 20.

40 Ibid. My own translation from the original: Stal i koguty - to też Indie. Przezdtugie lata widziano tylko barwna kogucia egzotykę tego wielkiego kraju. Teraz niejeden chciatby tu widzieć tylko żelazo. Ale życie i prawda tego kraju polega na tym, że koguty walcza na progu wielkich zaktadów, w których przetapia sie stal, p. 260. 
choosing their interviewees. It was definitely expected that the Polish journalists make contact with local progressives in order to show how a shared ideology dissolves cultural and national boundaries. The reporters were also visitors to the sites of socialist development, such as large factories or a city like Kolkata with a strong communist movement. The idea of socialist brotherhood, upheld in theory, is however marred by the often paternalist attitudes of the Polish visitors, maintaining a distant, if not ironic, gaze on people who were fellow communists in political terms, but cultural Others.

\section{THE INCOMPLETE SOCIALIST OR THE THIRD WAY}

The third distinctive feature of Polish reportage from India in the socialist era is that it often discusses Indian socialism as either incomplete, not fully formed and somewhat behind European socialisms, or as the Third Way, an interesting blend of local traditions and the belief in welfare state and socialist values. Clearly, depending on the period, the authors had more or less freedom to express their views; thought experiments involving the concept of the Third Way were only possible at a later stage. Jerzy Ros, travelling in mid-1950s, would not venture into such deliberations, but Wiesław Górnicki, author of a 1964 reportage Podróż po garść ryżu [Journey for a Handful of Rice], was already much freer in his intellectual enquiry into political theories. Jerzy Putrament, a representative of communist Poland's elite, was also less constrained in his opinions given his privileged position in the party hierarchy. ${ }^{41}$ As can be expected, the reporters visiting India in the first two decades after decolonization frequently focus on the figure of Jawaharlal Nehru, the follower of Gandhi and the first prime minister of independent India. They discuss his ideas on how to organize the independent state, how to plan its economy, and how to align - or non-align - with foreign powers in a world divided by the Cold War rivalry. The reporters consider India as a country that is on its way towards socialism, mostly thanks to Nehru's leadership. The features of this Indian model of semi-socialism are discussed at length by the reporters.

Putrament sees Marxism as directly connected to the decolonial thought, which in turn makes the decolonized states more prone to adopt socialist ideology: India today is a particularly instructive object of study for a Marxist. At the beginnings of the post-war decolonization process, the freshly created countries set off, by and large, from these [Marxist] starting positions. But from the very first moment, they chose different systemic principles. Almost all of them adopted general socialist declarations, although each of them understood them differently. So did China, and Egypt, and India... ${ }^{42}$

41 Putrament was famously depicted as Gamma in Czesław Miłosz's Captive Mind (1953), as an example of a communist intellectual.

42 J. Putrament, Na drogach... My own translation from the original: Dzisiejsze Indie sa niezwykle pouczajacym dla marksisty obiektem badań. W poczatkach powojennego procesu dekolonizacyjnego świeżo powstające państwa startowaty, z grubsza biorac, $z$ tychże pozycji wyjściowych. Ale od razu na początku wybraty one odmienne zatożenia ustrojowe. Wszystkie niemal przyjmowaty ogólne deklaracje socjalistyczne, kazde z nich jednak rozumiato je inaczej. I Chiny, i Egipt, i Indie..., p. 187. 
Putrament is aware that independence movements across the world would refer to Marxism at some point or another, but also that they would apply socialist principles selectively and in different ways. In Górnicki's opinion, this presents a danger: It is possible that while nurturing a wholesale sympathy to postcolonial states and believing in their natural development we omitted a moment of great importance in which the national bourgeoisie of these countries ceased to be a spring of progress and started to be its brake. ${ }^{43}$

Górnicki believes that India's elites, or national bourgeoisie, in spite of their allegiance to socialism, act now as a brake of progress. He is not alone in this opinion. Other reporters repeatedly express their dissatisfaction at the fact that Indian government does not implement more radical socialist reforms. They are convinced that the Polish public opinion has a distorted view of India and has too many illusions about its political leaders. Górnicki underlines that the generation of idealists like Nehru is dying out, the capital is accumulating, and that the future may be different from popular expectations. ${ }^{44}$ Hence, it is possible that the Eastern Bloc's hopes of India becoming a socialist ally will not come to a fruition.

The reporters realize that there are important differences between India and the communist countries of Eastern Europe. First, India chose socialism through parliamentary democracy, not through a revolution. Second, India is an enormous and diverse country. Only the principle of tolerance, Putrament suggests, could initially calm down the emerging conflicts, decrease the separatist tendencies and ensure the maintenance of national unity. Third, like in America, the government does not have the propaganda apparatus at its disposal, and the major dailies are in the hands of capitalists or right-wingers. ${ }^{45}$ The reporter believes that this weakened Nehru's position. He suggests that had India adopted the same model of concentration of media by the government and of censorship like in the Soviet Union, Nehru's position would not be threatened. Furthermore, the principles of peaceful coexistence of diversity and of a political plurality is in the long run problematic, says Putrament.

Thus, during its twenty years, the parliamentary democracy that was supposed to be a patron of the Indian incarnation of socialism not only failed to give this socialism a shape perceptible for the masses and to rely on these masses, but on the contrary, it allowed the most violent, right-wing, nationalist fanatics to reach these masses. Under the pretext of defending holy cows they are ready to convince the poor of India that their only salvation is the multiplication of Misters Tatas and letting them take care of the Indian people. ${ }^{46}$

43 W. Górnicki, Podróż po garść ryżu, Warszawa 1964. My own translation from the original: Bardzo możliwe, że żywiąc hurtowa sympatię do krajów postkolonialnych $i$ wierząc w ich naturalny rozwój przeoczyliśmy moment o wielkiej doniostości, w którym narodowa burżuazja tych krajów przestata być sprężyną postępu, a stata sie jego hamulcem, p. 186.

$44 \quad$ Ibid., p. 187.

45 J. Putrament, Na drogach..., p. 152.

46 Ibid. My own translation from the original: Tak więc demokracja parlamentarna, która miata patronować indyjskiemu wcieleniu socjalizmu, nie tylko przez dwadzieścia lat nie potrafita temu socjalizmowi nadać ksztattów uchwytnych dla mas i oprzeć się o te masy, ale wprost przeciwnie, pozwolita na to, że do tych mas zaczynaja się przerywać najgwattowniejsi, prawicowi, nacjonalistyczni fanatycy. Pod pretekstem 
Clearly, Putrament deplores the apparently decreasing appeal of socialism in India, and warns of the "fanatics", or the right-wing parties' domination. He is against any promotion of capitalism, personified by a famous industrialist Mister Tata. All India's problems, in Putrament's view, result from this lack of clear adoption of socialist values. A free coexistence of different parties - unlike in the Soviet model, in which there is only one, hegemonic party, the communist one - is at the crux of the problem, feels the writer. ${ }^{47}$

Another problematic issue in the context of Indian politics is, for the reporters, the idea of non-violence. Górnicki lists three important requirements for a truly socialist India. First, the limitation of political freedom for the owning class, second, a relative financial equality (which can only be reached through forms of legal coercion), and third, central planning. ${ }^{48}$ The reporter suspects that it would be hard to reconcile these principles with what he calls gandhism, and in particular the principle of satyagraha (nonviolent resistance), but he does not exclude this possibility. He finds that some of the Gandhian ideas have a certain value, especially the deep reflection on the fate of the individual, ${ }^{49}$ the idea of tolerance, the lack of arrogance, and the ability to question. However, certain modifications would be expedient: If these values could be boiled down to the role that they really deserve, filtered from the gibberish of mystics and from the hocus-pocus of reincarnation, and blended into rationalist socialism - India could perhaps reach some new synthesis, a political philosophy that is not yet known to us, but it is certainly familiar and useful. It is conceivable that such process will one day take place. India could then become one of the most important, most creative link of international socialism, its Medina and agora. ${ }^{50}$

Górnicki, in his usual, emphatic style proposes a blend of Indian philosophy with socialism, but only if certain ideas are rejected. These ideas - mysticism and the belief of reincarnation - are however at the core of Hindu beliefs, and Górnicki's rejection of them (in rather disparaging terms) makes his proposition of a fusion questionable.

Moreover, Górnicki realizes that Indian socialism remains a 'socialism' in quotation marks - it does not deliver on the promises of equality and progress. ${ }^{51}$ In his concluding remarks, he blames the rich countries of Europe and America for trying only superficially to help India, and accuses them of continuing the exploitation of the Subcontinent. He blames the local governments, too: The governments of non-socialist

obrony świętych krów gotowi są wmówić nędzarzom Indii, że jedyny dla nich ratunek - to rozmnożenie panów Tata i oddanie im troski o lud indyjski, pp. 193-194.

Ibid., p. 202

W. Górnicki, Podróż..., p. 196.

Ibid. My own translation from the original: gtęboki zamyst nad losem jednostki, p. 196.

Ibid. My own translation from the original: Gdyby sprowadzić te wartości do roli, jaka im rzeczywiście przypada, odsaczyć je z betkotu mistyków i guset reinkarnacji, wtopić w racjonalistyczny socjalizm - Indie dosztyby może do jakiejś nowej syntezy, do filozofii politycznej dziś nam jeszcze nieznanej, ale na pewno bliskiej i potrzebnej. Niewykluczone, że kiedyś taki process nastąpi. Indie mogtyby stać się wówczas jednym z najważniejszych, najbardziej twórczych ogniw światowego socjalizmu, jego Medyną i agorą, p. 197. 
postcolonial countries have not been able to challenge the terrible legacy of their past so far. I clearly say "non-socialist", because my journey to find the second formula of socialism has ended in a failure in all the countries I have visited. If we call socialism the Egyptian state capitalism and the Indian land reform, then I do not think we will be able to sort out this complicated semantics. ${ }^{52}$

Górnicki explains that the progress that the decolonized countries made is insufficient and ineffective in proportion to the scale of social problems, such as hunger, poverty, and inequality. What we often tend to treat as a particular wisdom of Asian leaders and ideologues or the joining of elements from opposing systems is in fact [...] the source of their doctrine's failure, argues Górnicki. Only socialism, together with sound philosophical foundations, can help end poverty. ${ }^{53}$ Even though Górnicki is somewhat disappointed with not having found that mythical Third Way, the postcolonial socialism, he considers his journey an important lesson. In the very last paragraphs of his account, he points in a subtle way to the responsibility of the well-off countries, both in the West and in the East (Poland, he notices, is a rich country, compared with India), for the backwardness and misery of the Third World. His solution is, surprisingly, disarmament, as he believes that only if the costs of arms and military development are reduced, there will be enough resources to fight global hunger and poverty. It is a rather bold statement for someone, who otherwise praises socialism. The pacifist appeal for disarmament, in a somewhat Gandhian spirit, is unexpected from someone, who finds Indian traditions of nonviolence to be brakes of progress.

Polish reporters have a troubled relationship with Indian socialism. On the one hand, they refer to socialism's promise of future development, trying to find examples of how India becomes more progressive and leftist, and how the countries of the Soviet Bloc can be helpful and lead the way. On the other hand, the reporters realize that the different context, culture, political and social structure make the direct export of Soviet-style socialism impossible. The mere fact that they acknowledge the failure of communism's implant on the Indian soil is already somewhat subversive, as it contradicts the official Soviet Bloc propaganda of global spread of communism. There is, however, a darker side to their conclusions, which unveils an underlying prejudice. Their accounts feature long and detailed descriptions of Indian culture and traditions, often presenting India as backward or contradictory to socialist modernity. Is it possible that the reporters

52 Ibid. My own translation from the original: Rządy niesocjalistycznych krajów postkolonialnych nie potrafity dotąd sprostać straszliwemu dziedzictwu przesztości. Powiadam krótko "niesocjalistycznych", ponieważ moja Podróż w poszukiwaniu drugiej formuty socjalizmu skończyta się fiaskiem we wszystkich krajach, które odwiedzitem. Jeżeli egipski kapitalizm państwowy i indyjską reformę rolna zaczniemy nazywaí socjalizmem, to nie sądzę, żebyśmy się mogli odnaleźć w gmatwaninie semantyki, p. 240.

53 Ibid. My own translation from the original: To zaś, co często jesteśmy sktonni brać za szczególnq madrość azjatyckich przywódców i ideologów, mianowicie kojarzenie elementów pobranych z przeciwstawnych ustrojów, jest wtaśnie źródtem... oczywistej porażki ich doktryn, pp. 241-242. 
simply do not believe that Indians could be fully modern? According to their logic, if Indians would become truly socialist, where would Poles be? The reporters' source of pride in developed social systems, the legendary advantage of free education, holidays and healthcare, would vanish, if Indian society reached the same level. The Polish experts would no longer be able to teach Indians how to build an electric power plant. This phenomenon was described by Homi Bhabha as mimicry - the Other should become like us, but not quite, not completely, in order for the colonial authority and dominant position to be maintained. ${ }^{54}$ Thus, the Polish reporters' take on India, although anti-colonial in purpose and ideology, bears traces of a colonial, superior, and paternalistic gaze on a former colony.

\section{BIBLIOGRAPHY}

Babiracki P., Jersild A. (eds.), Socialist Internationalism in the Cold War, Basingstoke 2016, https://doi.org/10.1007/978-3-319-32570-5.

Bhabha H., The Location of Culture, London-New York 1994.

Domosławski A., Kapuściński non-fiction, Warszawa 2010.

Engerman D.C., "Learning from the East: Soviet Experts and India in the Era of Competitive Coexistence", Comparative Studies of South Asia, Africa and Middle East, vol. 33, no. 2 (2013), pp. 227-238, https://doi.org/10.1215/1089201X-2322507.

Giełżyński W., Kraj świętych krów i biednych ludzi, Warszawa 1977.

Giełżyński W., Medytacje o Świecie Trzecim, Warszawa 1972.

Gołębiowski J., Nadane z Delhi, Warszawa 1966.

Górnicki W., Podróż po garść ryżu, Warszawa 1964.

Griffiths T.G., Cardona E.C., "Education for Social Transformation: Soviet University Education Aid in the Cold War Capitalist World-System", European Education, vol. 47 (2015), pp. 226-241, https://doi.org/10.1080/10564934.2015.1065390.

Hilger A., The Soviet Union and India: The Years of Late Stalinism, "Parallel History Project on Cooperative Security”, Swiss Federal Institute of Technology, IX 2008, at http://www.php. isn.ethz.ch/lory1.ethz.ch/collections/coll_india/intro_stalinee91.html?navinfo=56154.

Inden R., "Orientalist Constructions of India", Modern Asian Studies, vol. 20, no. 3 (1986), pp. 401-446, https://doi.org/10.1017/S0026749X00007800.

Kabbani R., Europe's Myths of the Orient, Bloomington, IN 1986, https://doi.org/10.1007/ 978-1-349-07320-7.

Klein C., Cold War Orientalism: Asia in the Middlebrow Imagination, 1945-1961, Berkeley-Los Angeles 2003, https://doi.org/10.1525/9780520936256.

Lisle D., Global Politics of Contemporary Travel Writing, Cambridge 2006, https://doi. org/10.1017/CBO9780511491535.

Mastny V., "The Soviet Union's Partnership with India", Journal of Cold War Studies, vol. 12, no. 3 (2010), pp. 50-90, https://doi.org/10.1162/JCWS_a_00006.

54 See H. Bhabha, The Location of Culture, London-New York 1994, pp. 85-88. 
Pratt M.L., Imperialne spojrzenie. Pisarstwo podróżnicze a transkulturacja, Kraków 2011.

Putrament J., Na drogach Indii, Warszawa 1967.

Ramachandran K.N., Nine Decades of the Communist Movement in India: From First to Tenth

Congress, at http://www.cpiml.in/cms/2015-04-21-11-52-27/history.

Rieber A., "Afterword: Promises and Paradoxes of Socialist Internationalism (Personal and Historical Reflections", in P. Babiracki, A. Jersild (eds.), Socialist Internationalism in the Cold War, Basingstoke 2016, pp. 327-343, https://doi.org/10.1007/978-3-319-32570-5_13.

Ros J., Indyjskie wędrówki, Warszawa 1957.

Said E.W., Orientalism, London 2003 (First edition: New York 1978).

Spurr D., The Rhetoric of Empire: Colonial Discourse in Journalism, Travel Writing, and Imperial Administration, Durham 1993, https://doi.org/10.1215/9780822398646.

Agnieszka SADECKA, Ph.D. is an assistant professor and lecturer at the Institute of European Studies of the Jagiellonian University in Krakow in the area of cultural and literary studies. She has obtained her doctoral degree from Eberhard Karls Universitaet Tuebingen in Tuebingen, Germany and the Jawaharlal Nehru University (JNU) in New Delhi, India. She is currently a researcher in the Horizon2020 research project "POPREBEL - Populist rebellion against modernity in $21^{\text {st }}$-century Eastern Europe: neo-traditionalism and neofeudalism" (2019-2021). Her academic interests revolve around $20^{\text {th }}$ - and $21^{\text {st }}$-century Polish culture, literature, and heritage, post-socialist cultures of Central and Eastern Europe, postcolonial/post-dependency studies, identity, as well as socio-cultural dimensions of populism and nationalism. 